\title{
Uropodina mites (Acari: Mesostigmata) from agricultural areas of Ecuador
}

\author{
J. KONTSCHÁN \\ Jenö Kontschán, Plant Protection Institute, Centre for Agricultural Research, Hungarian Academy of \\ Sciences, H-1525 Budapest, P.O. Box 102, Hungary.E-mail: kontschan.jeno@agrar.mta.hu
}

\begin{abstract}
Soil and leaf-litter samples of several agroecosystems (banana, cacao, coffee, and Monterey pine plantations) in Ecuador were investigated regarding soil dwelling Uropodina. Short notes are given on the plantations and on the recorded mite species with description of a species new to science; Clivosurella zicsii sp. nov. Furthermore, diagnosis of the genus Clivosurella Hirschmann, 1979 is presented with a new key to the known species.
\end{abstract}

Keywords. Acari, Uropodina, new species, agroecosystems, Ecuador.

\section{INTRODUCTION}

$\mathrm{T}$ he renown earthworm taxonomist and soil biologist András Zicsi organized numerous collection trips together with Imre Loksa and later with Csaba Csuzdi to Ecuador (Zicsi \& Csuzdi 2008). These trips resulted in many scientific contributions to the knowledge of the Ecuadorian soil dwelling animals, like nematodes (Andrássy 1997) and earthworms (Zicsi 1989, 2002, 2007). In addition, several papers were focused on the soil dwelling mites, especially on the members of the suborder Uropodina (e.g. Kontschán 2008a, b, 2012).

Uropodina or turtle-mites are one of the characteristic groups of the soil dwelling Acari which reaches its highest diversity in the tropical soils (Lingquist et al. 2009). Hirschmann and his coauthors discovered and described 54 Uropodina species from Ecuador (including the Galapagos Archipelago) mostly based on the collections of the Hungarian soil zoologists (see the summary list in Wiśniewski 1993). Beside Hirschmann, Elzinga (1981, 1982, 1995) and Elzinga \& Rettenmeyer $(1970,1975)$ described eight new Uropodina species collected from the body of the Ecuadorian army ants. Subsequently Kontschán (2008a,b, 2010, 2011, 2012) and Kontschán \& Starý (2013) presented new species from Ecuador.

All these studies focused on natural habitats (mostly rain forests), but we did not get any information about the Uropodina fauna of agricultural soils in South- and Central-America.

Here, I would like to complete these deficiencies reporting on the soil dwelling mites collected in Ecuadorian agricultural fields.

\section{MATERIAL AND METHODS}

Specimens were cleared in lactic acid and drawings were made with the aid of a drawing tube attached to a Leica DM 1000 scientific microscope. All specimens are stored in ethanol and deposited in the Hungarian Natural History Museum in Budapest (HNHM) and the Natural History Museum in Geneva (MHNG).

Setal nomenclature follows that of Kranzt \& Walter (2009). Abbreviations: $\mathrm{h}=$ hypostomal setae, $\mathrm{St}=$ sternal setae, $\mathrm{V}=$ ventral setae. All measurements and the scales in the figures are given in micrometers $(\mu \mathrm{m})$. 


\section{RESULTS}

\section{Cocoa}

Background. Cocoa trees have been cultivated firstly in Central America, but nowadays are planted in Africa and in Asia as well. In the humid tropical areas it is an important cultivated plant, currently about 6.5 million hectares are planted in more than 50 countries (Wood \& Laas 2001). Cocoa plantations have a significant role in tropical biodiversity conservation; the cocoa agroforestry can be important refuge for several plant and animal species (Schrot \& Harvay 2007).

Material examined. Ecuador, (Ecu.1990. B. 13.) Prov. Manabi. $7 \mathrm{~km}$ after Flavio Alfaro 300 m., 20. IV. 1990, leaf litter from Cocoa plantation, leg. Zicsi, A. \& Csuzdi, Cs.

Uropodina species. Three already described and named Uropodina were found in this sample: Ungulaturopoda ungulata (Hirschmann \& Hiramatsu, 1977), Kaszabjbaloghi kaszabi Hirschmann, 1973 and Clivosurella porosa (Hirschmann, 1972). The species Ungulaturopoda ungulata belongs to the family Cillibidae (Kontschán 2012), which usually occurs in natural habitats of Ecuador (Kontschán 2012) similarly to the species Kaszabjbaloghi kaszabi. The third species, Clivosurella porosa was collected only in Brazilian rain forests so far. This is the first Ecuadorian record of the species.

\section{Coffee}

Background. The coffee bush is of Ethiopian origin, widely introduced in the old and new world tropics (Perfecto et al. 1996). The coffee production has an important economical role in the Neotropical countries (Gobbi 2000), for example in El Salvador coffee is the most important agricultural export commodity representing $30 \%$ of the country's total exports. Beside the economic importance, the coffee plantations have significant role in the preservation of the tropical biodiversity (Perfecto et al. 1996).
Material examined. Ecuador, (Ecu. B. 38.) Prov. Napo. $12 \mathrm{~km}$ before Loreto, coffee plantation, 450 m. 2. V. 1990, leaf litter, leg. Zicsi, A. \& Csuzdi, Cs.

Uropodina species. A single Uropodina species is recorded from this sample; Clivosurella porosa (Hirschmann, 1972).

\section{Monterey pine (Pinus radiata D. Don)}

Background. The Monterey pine is one of the most often planted pine species in the world. The largest plantations are cultivated in Australia, New Zealand, Chile, Spain South-Africa, but smaller forests can be found in other countries (e.g. Kenya) as well (Mead 2013). The soil dwelling mites of the Pinus radiata plantations have already been summarized by Kontschán (2015), with description of two new species furthermore, in the very same year the third species of the Afrotropical endemic genus, Bloszykiella Kontschán, 2010 was discovered and described from leaf litter of Monterey pine plantation in Kenya (Kontschán \& Starý 2015).

Material Examined. Ecuador, (Ecu. 1986 Berl. 123.), on the way to Pujili, Pinus radiata plantation (about 40 years old), 2800 m, 16. II. 1986, mossy litter and soil from below trees, leg. Loksa, I. \& Zicsi, A.

Uropodina species. Numerous specimens of Rotundabaloghia (Circobaloghia) ecuadorensis Hirschmann, 1992 were found in this sample. This mite seems to be common in natural habitats of Ecuador (Kontschán 2008), and this is its first record from an agricultural area.

\section{Banana}

Background. Banana is one of the most important agricultural plants, which occurs in the equatorial zones of the world. Banana fruit is an important and cheap food, while other parts of the plant can be used as building materials (Hallam 1995). The investigated sample was not taken in a 
typical agricultural area; it is originated from a forest where some banana trees were found, and the trees were probably cultivated.

Material examined. Ecuador, (Ecu. Berl. 178. Saloya (Prov. Pichincha), 1450 m, 20. II.1986, litter and soil from forest edge with banana plants.

Uropodina species. The banana leaf litter material contained two species, the herein described new one: Clivosurella zicsii sp. nov. and the Neotropical Uroobovella faceta Hiramatsu \& Hirschmann 1978, which was listed earlier from Ecuador and Costa-Rica (Kontschán 2009).

\section{Descriptions}

\section{Genus Clivosurella Hirschmann, 1979}

Clivosurella Hirschmann, 1979: 59.

Clivosurella: Kontschán 2010: 332, Halliday 2015: 109.

Diagnosis. Idiosoma pentagonal, marginal shield forms a trapezoid pygidial shield on caudal area of dorsal body. Central part of dorsal shield elevated from the neighboring regions. Genital shield of female scutiform. Internal malae apically or marginally pilose, setae h1 long and smooth. Chelicerae with internal sclerotized node.

Type species. Discourella clivosa Hirschmann, 1972: 34, by original designation.

Distribution. All described Clivosurella species occur in the Neotropical area, in Brazil, Venezuela and Ecuador (Kontschán 2010).

Notes. Originally, the genus Clivosurella was a species group (clivosa species group) of the genus Discourella and was elevated to generic rank by Hirschmann (1979). Although this newly described genus differs by several characters from the genus Discourella, later Hirschmann (1993) and his co-workers (Wiśniewski 1993, Wiśniewski \& Hirschmann 1993) placed it back again into the genus Discourella, as the clivosa species group. Subsequently, Kontschán (2010) mentioned again this name and elevated it to generic rank.

\section{Clivosurella zicsii sp. nov.}

(Figures 1-14)

Material examined. Holotype. Female (HN HM), Ecuador, (Ecu. Berl. 178.) Saloya (Prov. Pichincha), $1450 \mathrm{~m}, 20$. II.1986, litter and soil from forest edge with banana plants. Paratype. Female (NHMG), locality and date same as of holotype.

Diagnosis. All marginal setae phylliform and marginally finely serrate. Majority of dorsal setae short, phylliform and marginally serrate. Pygidial shield fused to marginal shield on caudal part. All body covered by irregular pits. One pair of supplementary sternal setae present, genital shield of female linguliform and its surface smooth.

Description of female. Length of idiosoma 600-620 $\mu \mathrm{m}$, width 440-450 $\mu \mathrm{m}(\mathrm{n}=2)$. Shape pentagonal, color reddish brown.

Dorsal idiosoma (Fig. 1). Marginal and dorsal shields fused anteriorly. Setae on dorsal shield, wide, phylliform and marginally serrate (Fig. 2) majority of dorsal setae short (ca. 18-22 $\mu \mathrm{m})$, except two pairs of longer setae ( $c a .45-48 \mu \mathrm{m}$ ) situated close to caudal edges of dorsal shield. Surface of dorsal shield with numerous large irregular pits on anterior area and smaller oval pits on other parts of dorsal shield. Central part elevated from the neighboring area, lateral margins of elevated area strongly sclerotized and forming C-shaped parts. Marginal shield covered by irregular pits and bearing large, phylliform, marginally serrate setae (ca. 25-27 $\mu \mathrm{m})$ (Fig. 3), on anterior area of marginal part of body bearing larger $(c a .50-55 \mu \mathrm{m})$ phylliform, marginally serrate setae (Figs. 4-5). Pygidial shield trapezoid, covered by irregular pits, bearing three pairs of marginally serrate phylliform setae (ca. 43-45 $\mu \mathrm{m})$ and caudally fused to marginal shields.

Ventral idiosoma (Fig. 6). Majority of surface of sternal shield smooth, but some oval pits situated between coxae I. Sternal (St1-St6) setae short $(c a .8-10 \mu \mathrm{m})$, smooth and needle-like. St1 and St2 situated at level of central area of coxae II, St3 at level of central area of coxae III, St4 at level of central area of coxae IV, St5 at level of 

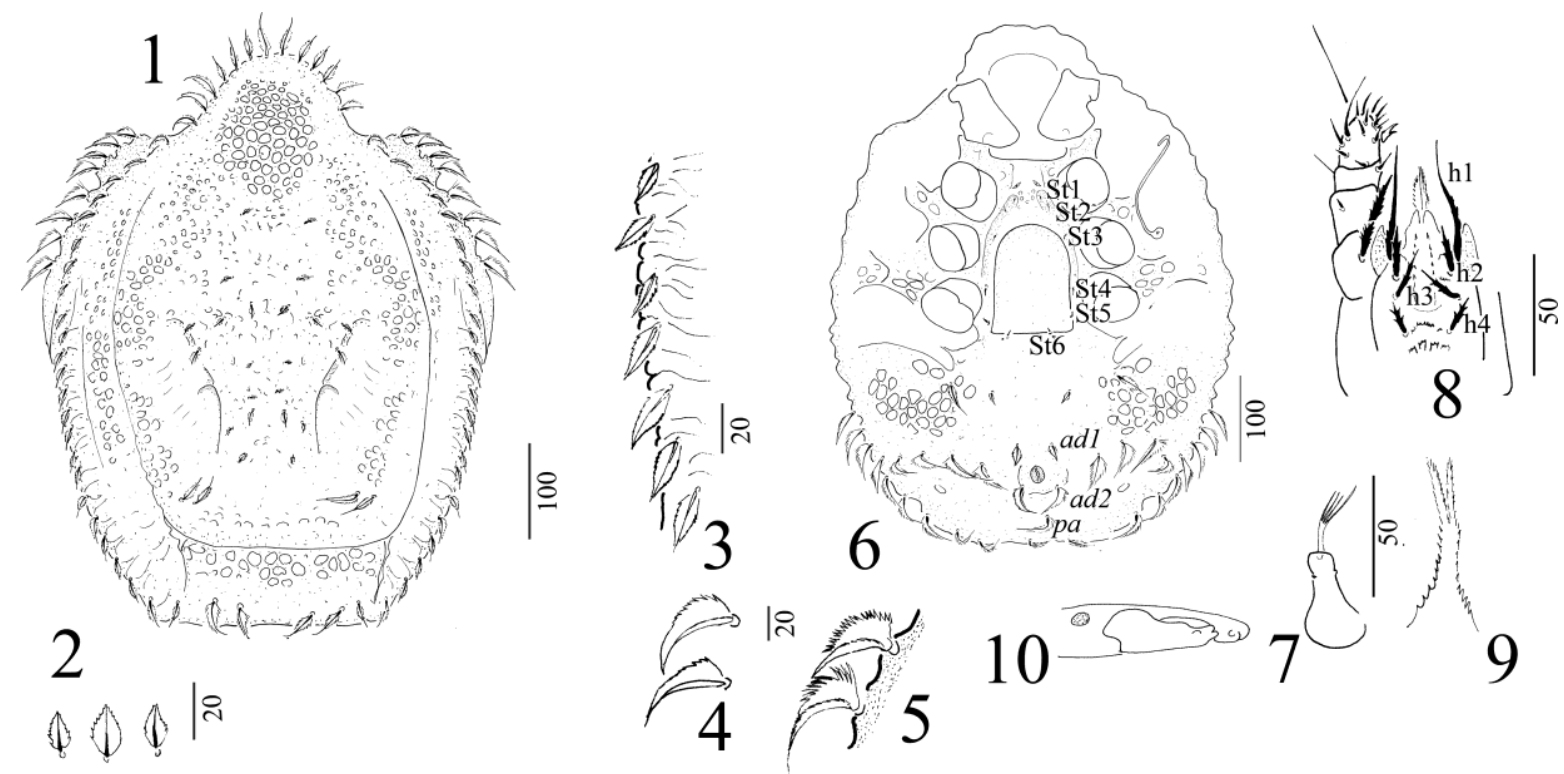

Figures 1-10. Clivosurella zicsii sp. nov. female, holotype, $1=$ body in dorsal view; $2=$ dorsal setae; $3=$ marginal setae, 4 and $5=$ setae on anterior margins; $6=$ body in ventral view; $7=$ tritosternum; $8=$ ventral view of gnathosoma and palp; $9=$ epistome; 10: lateroventral view of chelicera.

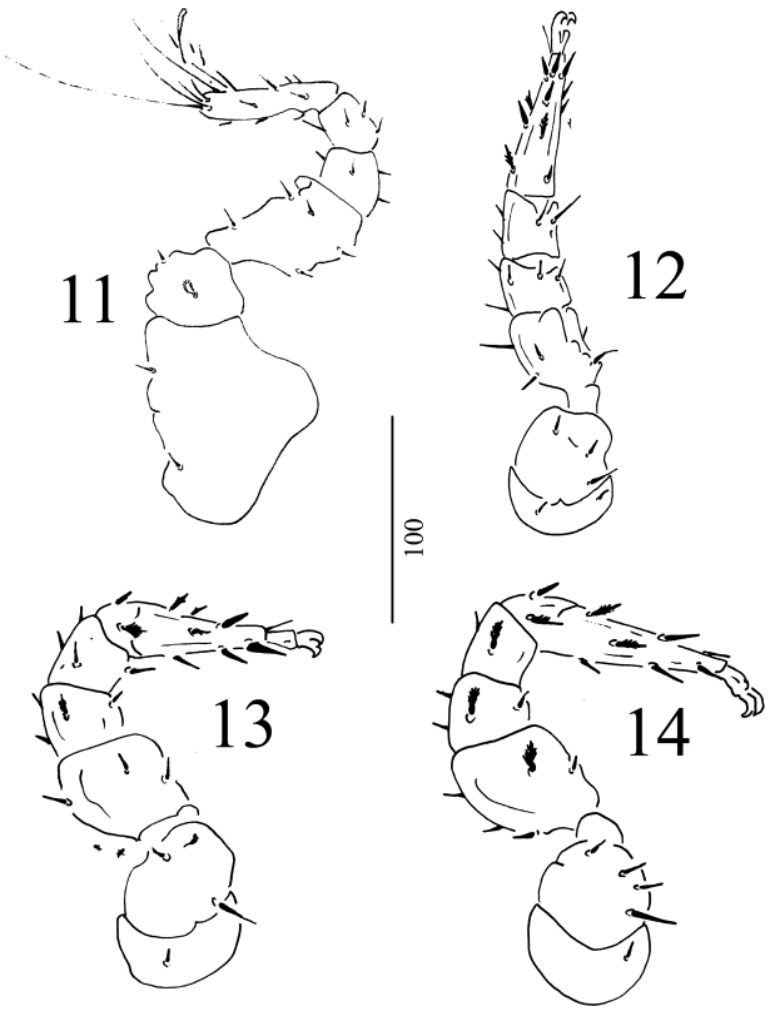

Figures 11-14. Clivosurella zicsii sp. nov. female, holotype, 11 = ventral view of leg I; $12=$ ventral view of leg II; $13=$ ventral view of leg III; $14=$ ventral view of leg IV. posterior margin of coxae IV, St6 close to basal line of genital shield. St1-St4 situated on strongly sclerotized area around anterior part of genital opening. All setae on ventral idisoma phylliform, marginally serrate, first pair short (ca. 17-18 $\mu \mathrm{m})$, others long (ca. 44-48 $\mu \mathrm{m})$. Adanal setae adl shorter $(c a .22-23 \mu \mathrm{m})$ than $a d 2$ and postanal seta (pa) (ca. 37-38 $\mu \mathrm{m})$, but same shape as of ventral setae. Irregular pits situated posterior to pedofossae IV and close to outer part of coxae II and III. One pair of lyrifissures situated anterior to St1 and one pair of poroid close to St6. Stigmata situated close to coxae III. Prestigmatid part of peritremes hook-shaped, poststigmatid part absent. Genital shield linguliform, anterior margin rounded its surface smooth. Pedofossae deep, their surface smooth, separated furrows for tarsi IV absent. Base of tritosternum pear-like with one pair of lateral spines, tritosternal laciniae subdivided into four smooth branches (Fig. 7).

Gnathosoma (Fig. 5). Corniculi horn-like, internal malae smooth and longer than corniculi. All hypostomal setae marginally serrate, $\mathrm{h} 1$ long (ca. 50-52 $\mu \mathrm{m}), \mathrm{h} 2, \mathrm{~h} 3$ and $\mathrm{h} 4$ shorter (ca. 17-20 $\mu \mathrm{m})$. Apical part of laprum marginally pilose. One pair of row of denticles situated on the ventral 
part of gnathosoma and internal malae from $\mathrm{h} 2$ till at level of corniculi. Palp tochanter with two long and robust marginally serrate setae, other setae on palp smooth and needle-like. Epistome marginally serrate and apically divided into two marginally pilose branches (Fig. 9). Chelicerae with internal sclerotized node, fixed digit longer than movable digit, movable digit with two apical and one lateral tooth, apical part of fixed digit with a pitlike sensory organ (Fig. 10).

Legs (Figs. 11-14). Leg I without claws on tip of tarsi. Marginally serrate and needle-like setae situated on each leg.

Male, larva and nymphs unknown.

Etymology. I dedicate the new species to the memory of Prof András Zicsi, the noted earthworm specialist, who collected soil samples all across Ecuador.

\section{Key to the known females of the genus Clivosurella (after Kontschán 2010, modified)}

1. Genital shield bearing ornamentation................................ 2

- Genital shield without ornamentation................................... 4

2. Whole surface of genital shield ornamented...................... 3

- Genital shield ornamented anteriorly...................... .C. brasilica Kontschán, 2010

3. Depression on ventral shield near anterior region of anal opening with irregular pits....... . venezuelensis (Huţu, 1987)

- Depression on ventral shield near anterior region of anal opening without pits............... C. simonbolivari (Huţu, 1987)

4. Genital shield linguliform

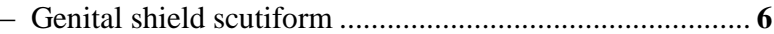

5. Setae on marginal shields smooth and needle-like ............. .. C. frondosa (Hirschmann, 1972)

- Setae on marginal shields phylliform and marginally ..serrate $\boldsymbol{C}$. $z \boldsymbol{i} \boldsymbol{i c s i \boldsymbol { i } \text { sp. nov. }}$

6. Ventral shield with alveolar pits C. deraiophoroides (Hirschmann, 1972)

- Ventral shield without alveolar pits. C. porosa (Hirschmann, 1972)

Notes to the key. Only male specimens are known of C. brasiliensis (Hirschmann, 1972), C. clivosa (Hirschmann, 1972) and C. spumans (Hirschmann, 1972). All the three species have smooth and needle-like dorsal setae therefore they are easy to separate from the new species on the basis of this character.

\section{DISCUSSION}

All the Uropodina species found were listed earlier only from natural habitats of the Neotropical region. These species usually belong to the more common Neotropical Uropodina, but there is very few information about their habitat preferences. Maybe it can be true also for soil dwelling Uropodina that some tropical agricultural areas are good refuges for these species and thus these areas contribute significantly to biodiversity (Gobbi 2000, Perfecto et al. 1996, Schrot \& Harvay 2007).

Four of the species found belong to the endemic Neotropical genera Ungulaturopoda, Kaszabjbaloghia and Clivosurella, which are known only from Ecuador, Brazil, Costa-Rica and Columbia. The subgenus Rotundabaloghia (Circobaloghia) has a circumtropical distribution type; members of this subgenus can be found in all tropical regions. The Uroobovella species found is an extremity. This species belongs to the Uroobovella elengans-group, the members of this group occur only in South-East Asia and AustralAsia (Wiśniewski 1993), except a single species $U$. faceta that lives in the Neotropical region therefore it can be an example of the amphipacific distribution type.

Acknowledgements - This study was supported by the Hungarian Scientific Research Fund (OTKA 108663). I am grateful for Dr. Balázs Kiss for the linguistic corrections of the text and the anonymous reviewers for their valuable comments.

\section{REFERENCES}

ANDRÁSSY, I. (1997): Nematodes from Ecuador. A new genus, four new and a known species (Dorylaimida). Opuscula Zoologica Budapest, 29-30: 3-19.

ELZINGA, R.J. (1981): The generic status and six new species of Trichocylliba (Acari: Uropodina). Acarologia, 23(1): 3-18.

ElzINGA, R.J. (1982): The genus Antennequesoma (Acari: Uropodina) and description of four new species. Acarologia, 23(4): 319-325. 
ElzINGA, R.J. (1995): Six new species of Trichocylliba (Acari: Uropodina) associated with army ants. Acarologia, 36(2): 107-115.

ElzingA, R. J. \& RETTENMEYER, C. (1970): Five new species of Planodiscus (Acarina: Uropodina) found on doryline ants. Acarologia, 12(1): 59-70.

ElzingA, R. J. \& RETTENMEYER, C. (1975): Seven new species of Circocylliba (Acarina: Uropodina) found on army ants. Acarologia, 16(4): 595-611.

GoBBI, J.A. (2000): Is biodiversity-friendly coffee financially viable? An analysis of five different coffee production systems in western El Salvador. Ecological Economics, 33: 267-281. doi: 10.1016/S0921-8009(99)00147-0

HALLAM, D. (1995): The world banana economy. In: Gowen, S. (Ed.) Bananas and Plantains. Word Crop Series, Springer, p. 509-553. doi: $\underline{10.1007 / 978-94-011-0737-2 \_19}$

HALLIDAY, R.B. (2015): Catalogue of genera and their type species in the mite Suborder Uropodina (Acari: Mesostigmata). Zootaxa, 3972(2): 101-147. doi: 10.11646/zootaxa.3972.2.1

HiRschmanN, W. (1979): Stadiensystematik der Parasitiformes Teil 1. Stadienfamilien und Stadiengattungen der Atrichopygidiina, erstellt im Vergleich zum Gangsystem Hirschmann, 1979. Acarologie. Schriftenreihe für Vergleichende Milbenkunde, 26: 57-68.

HIRSCHMANN, W. (1993:) Gangsystematik der Parasitiformes Teil 550. Bestimmungstabellen der Uropodiden der Erde, Atlas der Ganggattungen der Atrichopygiina. Acarologie. Schriftenreihe für Vergleichende Milbenkunde, 40: 292-370.

KontschÁN, J. (2008a): New and rare Rotundabaloghia species (Acari: Uropodina) from the tropics. Opuscula Zoologica Budapest, 38: 15-41.

KontSCHÁN, J. (2008b): A review of the Neotropical family Tetrasejaspidae (Acari: Uropodina) with descriptions of three new species. Opuscula Zoologica Budapest, 37: 29-42.

Kontschán, J. (2010): New and little known Uropodina species from Brazil (Acari: Mesostigmata). Acta Zoologica Academiae Scientiarum Hungaricae, 56(4): 317-334.

KontSCHÁN, J. (2011): Six new species of family Trachyuropodidae from the Neotropical region
(Acari: Mesostigmata: Uropodina). Studies on Neotropical Fauna and Environment, 46(3): 211-223. doi: 10.1080/01650521.2011.618034

KONTSCHÁN, J. (2012): Notes on the distribution and taxonomy of the Ecuadorian Uropodina mites (Acari: Mesostigmata). Opuscula Zoologica Budapest, 43(1): 27-42.

KontschÁN, J. (2015): Two new Uropodina species (Acari: Uropodidae) from a Pinus radiata plantation in Kenya. Acta Zoologica Academiae Scientiarum Hungaricae, 61(1): 33-45. doi: $\underline{10.17109 / \text { azh.61.1.33.2015 }}$

KONTSCHÁN, J. \& StARY, J. (2013): Three new Trachyuropoda (Acari: Uropodina: Trachyuropodidae) species from the Neotropical region. Turkish Journal of Zoology, 37: 7-14. doi: 10.3906/zoo-1204-24

KONTSCHÁN, J. \& StARY, J. (2015): First record of the genus Bloszykiella in Kenya with the description of Bloszykiella tertia sp. n. (Acari: Uropodidae) from a Pinus radiata D. Don plantation. African Invertebrates, 56(3): 629-635.

KrantZ, G.W. \& Walter, D.E. (2009): A Manual of Acarology, Third Edition. Texas Tech University Press, Lubbock Texas, 807 pp.

LindQuist, E.E., KrantZ, G.W.\& WALTER, D.E. (2009): Order Mesostigmata. In. KRANTZ G.W. \& WALTER, D.E. (Eds.) A Manual of Acarology. Third edition. Texas University Press, Lubbock, USA, p. 124-232.

MEAD, D. J. (2013): Sustainable management of Pinus radiata plantations. FAO Forestry Paper No. 170. Rome, FAO, 246 pp.

Perfecto, I., Rice, R.A., GreenberG, R. \& E. VAN DER VOORT, M. (1996): Shade coffee: a disappearing refuge for biodiversity. BioScience, 46(8): 598-608.

Schrot, G. \& Harvay, C.A. ( 2007): Biodiversity conservation in cocoa production landscapes: an overview. Biodiversity and Conservation, 16(8): 2237-2244. doi: 10.1007/s10531-007-9195-1

WIŚNIEWSKI, J. (1993). Gangsystematik der Parasitiformes Teil 549. Die Uropodiden der Erde nach Zoogeographischen Regionen und Subregionen geordnet (Mit Angabe der Lande). Acarologie. Schriftenreihe für Vergleichende Milbenkunde, 40: 221-291. 
WIŚNIEWSKI, J. \& HIRSCHMANN, W. (1993): Gangsystematik der Parasitiformes Teil 548. Katalog der Ganggattungen, Untergattungen, Gruppen und Arten der Uropodiden der Erde. Acarologie. Schriftenreihe für Vergleichende Milbenkunde, 40: 1-220.

WoOD, G.A.R. \& LAAS, L.A. (2001): Cocoa. Forth Edition. Blackwell Science, Oxford, 610 pp.

ZICSI, A. (1989): Über drei neue Andiodrilus-Arten Ecuador (Oligochaeta: Glossoscolecidae). (Regenwürmer aus Südamerika 12). Revue suisse de Zoologie, 96: 771-777. doi: 10.5962/bhl.part.82060

ZICSI A. (2002): Eine neue Art der Gattung Zongodrilus Righi, 1995 sowie weitere Arten der
Familie Glossoscolecidae (Oligochaeta) aus Ekuador. Regenwürmer aus Südamerika 37. Opuscula Zoologica Budapest, 34: 113-123.

ZICSI, A. (2007): An annotated checklist of the earthworms of Ecuador (Oligochaeta). Earthworms from South America 42. In. BROWN, G.G. \& Fragoso, C. (Eds.) Minhocas na América Latina: Biodiversidade e Ecologia, Embrapa, Londrina. p. 167-192.

ZICSI, A. \& CsUZDI, Cs. (2008): Report on the soilzoological expeditions to Ecuador and Colombia between 1986-1993. I. list of localities and habitats of "Berlese" samples. Opuscula Zoologica Budapest, 37: 71-88. 